\title{
Cemil Süleyman'ın Siyah Gözler Romanından Hareketle Bir Kadının Paranoid Bozuklukları
}

\section{Paranoid Disorders Of A Woman Based On The Novel Of Cemil Suleyman's Siyah Gözler}

\author{
NAZLI MEMIŞ BAYTIMMUR* \\ * Arş. Gör. Dr., Sinop Üniversitesi Fen Edebiyat Fakültesi Türk Dili ve Edebiyatı Bölümü, \\ nmbaytimur@sinop.edu.tr
}

ORCID Numaras1 | ORCID Number: 0000-0001-7591-1122

ÖZ

\begin{abstract}
Fiktif bir âlemin üzerine şekillenen romanın hayatla ve gerçekle olan sıkı bir bağı vardır. Ruhsal bozukluklar da hayata ve gerçeğe dair olup edebi eserlerin içeriğinde bulunan bir durumdur. Yazarlar, bu gibi bozuklukları bazen anlatmak bazen de kurguya derinlik kazandırabilmek için kullanmışlardır. Tanzimat Dönemi’nde Ahmed Midhat Efendi, Nabizâde Nâzım, Samipaşazâde Sezai gibi yazarların romanlarında kısmen ele alınan ruhsal bozukluklar, Servet-i Fünûn Dönemi'ne gelindiğinde Halid Ziya ve Mehmed Rauf gibi yazarların romanlarında kapsamlı ve çarpıcı bir şekilde kurguda yer almaya başlar. Ancak Türk Edebiyatı'nda ruhsal bozuklukların bir çeşidi olan paranoid bozuklukların bir roman kahramanı ekseninde ele alınıp işlenmesi ilk kez 1911 yılında yayımlanan Cemil Süleyman'ın Siyah Gözler eseri ile gerçekleşir. Romanın ismi belli olmayan kadın kahramanı, paranoid bozukluğun persekütuar ve kıskançlık tiplerini bütünleştirerek yansıtır. Güvensiz ve kuşkucu tavırları ile ön plana çıkan kadın, âşık olduğu genç adamın her davranışını gerçekten uzaklaşarak yorumlar. Bu durum onun hem toplumla hem de sevdiğiyle olan ilişkisinin gitgide bozulmasına sebep olur. Romanın sonunda kadın, dış dünyadaki uyaranların onu yanlış yönlendirmeleri ve kendi inandığı düşüncelere dayanarak hareket etmesiyle delikanlıyı boğarak öldürür. Bu durum, kadının paranoid bozuklarının sonucunda yaşadığı gerçeklik deneyimindeki ciddi orandaki yitimin bir tezahürüdür.
\end{abstract}

Anahtar Kelimeler: Roman, Ruhsal bozukluklar, Paranoid bozukluklar, Persekütuar tip, Kıskanç tip.

\section{ABSTRACT}

The novel is based on the fictional world and has a close connection to life and reality. Mental disorders are related to life and reality anda re found in the content of literary works. The authors sometimes used to describes such disorders and sometimes to give depth to fiction. In the period of Tanzimat, the mental disorders discussed partly in the novels of writers such as Ahmed Midhat Efendi, Nabizade Nazim, Samipaşazade Sezai began to take place strikingly in the fiction of writers such as Halid Ziya and Mehmed Rauf in the period of Servet-i Fünun. However, paranoid disorders, which are a kind of mental disorders in Turkish Literature, are handled and processed in the axis a novel heroine that is the work of Cemil Suleyman's Siyah Gozler which was published in 1911 for the first time. The heroine of the novel whose name is not known reflects the types of persecution and jealousy of the paranoid disorder. The woman, who comes to the fore with her unsafe and suspicious behavior, interprets the every action of the young man she falls in love with away from the reality. This situation disrupts the relation with both the society and her darling. At the end of the novel, the woman strangles the young man as a result of misleading warnings from the outside world and her own devotion. This is a manifestation of the serious decrease in the experience of reality experienced by the woman as a result of paranoid disorders.

Keywords: Novel, Mental disorders, Paranoid disorders, Persecutory type, Jealous type. 


\section{Giriş}

1908 yılında ilân edilen II. Meşrutiyet'le beraber basın organları üzerindeki sansür kaldırılır. $\mathrm{Bu}$ durum, düşünce hayatının yeniden faaliyete geçmesine olanak vererek yeni gazete ve dergilerin piyasaya çıkmasını sağlar. Söz konusu dönem içerisinde edebiyatın sorunlarını ele alan, Servet-i Fünûn etkisini üzerlerinde taşıyan şair ve yazarlar, edebiyat dünyasına yeni bir soluk getirme niyetiyle bir topluluk oluşturmaya karar verirler. Fâik Ali'nin isim babalığı yaptığı bu topluluğa Fecr-i Âti adı verilir. Bir bildiri ile edebiyat dünyasına adım atarak 1909 yılında kurulan bu topluluk 1912 yılında dağılmış olup ömrü kısa sürer. Bu topluluğun temsilcilerinden birisi de Cemil Süleyman'dır.

Edebi hayatına öykü yazarak başlayan sanatkâr, aynı zamanda Fecr-i Âti topluluğunun başlattığı "Fecr-i Âti Kütüphanesi” yayın dizisinin ilk kitabı olan Timsâl-i Aşk'1 yayımlayan yazardır. Söz konusu eser, onun edebi ürünlerini ilk derlediği kitap olması ile de önem teşkil eder. Ardından yayımladığı Ukde adlı kitabı da yine öykülerini bir araya getirdiği bir eserdir. Bu iki kitapta yer alan öyküler, Servet-i Fünûn'a tepki olarak doğmasına karşın onun etkisinden çıkamayan Fecr-i Âti topluluğu yazarlarının edebi anlayışlarının izlerini taşır ve fiktif âlemdeki kişileri duygusal yönden ele alır. Onun "ideal sevgi ve insan arayışı içerisindeki, şahsın ya da ben'in bir bilincin dökümü halinde" (Berksoy, 2003, s. 12) yazıya aktardığı öykülerde kişilerin ruhsal derinliklerini yansıtma çabası içinde olduğu görülür.

Yazarın İnhizâm ve Kadın Ruhu adlı romanları tefrika olarak yayımlanmış olup kitaplaşmamıştır. Fecr-i Âti topluluğunun bir mensubu olmasına rağmen, eserlerinde Halid Ziya ve Mehmed Rauf'un etkisi göze çarpar. Onun Siyah Gözler romanı, Türk Edebiyatı'nda psikolojik öğeleri ön planda işlemesinin dışında ruhsal bir bozukluk olan paranoid bozuklukları bir kadın kahraman aracılığıyla dramatik bir şekilde ele alması ile bir ilktir. Bu çalışmada, söz konusu romanındaki kadın kahramanın paranoid bozuklukları, bilimsel verilerden hareketle irdelenmeye çalışılmıştır.

\section{Ruhsal Bozuklukların Tarihçesi}

Ruhsal bozukluk, kişinin bilişsel, duygusal yetilerinde, davranışlarında, çevreye uyumunda görülen aksaklıklar neticesinde açığa çıkar. İnsanlık tarihi kadar eski olan bu gibi bozukluklar, ilkel çağlardan günümüze kadar çeşitli merhalelerden geçmiştir. Eski Yunan-Roma döneminde ruhsal bozukluklar doğaüstü güçlere bağlanır ve bunların yine doğaüstü zararlı ruhlardan geldiğine inanılır. Bunları iyileştirmek amaciyla büyücü hekimler ve şamanlar çeşitli törenlere, dualara, değişik hareketlere, nöbetlere ve "ruhları saklayan eşyanin yok edilmesi gibi uygulamalar"a (Öztürk ve Uluşahin, 2011, s. 2) başvururlar. Doğa karşısında aciz olan ilkel insan, korku ve güvensizlik içinde anlamlandıramadığı güçlere sığınarak bu olguyu anlamaya ve kendini bundan korumaya çalışmıştır.

Eski Yunan'ın Perikles döneminde yaşamış olan Hipokrat, ruh hastalıklarının doğaüstü güçlere değil doğal faktörlere bağlı olduğunu bilimsel veriler 1şığında gösterir. Hipokrat'tan sonra Eflatun, Aristo, Cicero, Aretaeus, Galegon gibi bilginler de Hipokrat'1n görüşlerini takip ederek "gizemci-büyüsel düşüncenin geçersizliğini" (Öztürk ve Uluşahin, 2011, s. 3) kanıtlamışlardır.

Orta Çağ'a gelindiği zaman ruh hastalıklarının bilimsel faktörlere dayandığı düşüncesi yerini yine doğaüstü güçlerden kaynaklandığına inanılan bilim dışı görüşe bırakır. Tibbî araştırmaların gerilemeye başladığı bu dönemde tedavide ilaç yerine ilahilere, çeşitli şerbetlere, muskalara ve fallara başvurulmaktadır. Bununla birlikte dinsel açıklamalar çerçevesinde ruh hastalarına insanlık dışı işkenceler yapılmakta ve bu insanlar öldürülmektedir. Ancak 13. ve 14. yüzyıldan itibaren yapılan bu acımasız uygulamalara karşı toplum tepkisini giderek yükselen bir ölçüde göstermeye başlar. Yeni 
düşünce akımlarının ortaya çıkışı ile Martin Luther ve onu destekleyen kitlelerin dogmatik din anlayışına isyanı sonucunda Avrupa'da büyük bir kültürel devrim vücuda gelir.

16. ve 17. yüzyıldan sonra tıp alanında çok önemli değişiklikler yaşanır. Yine bu dönem içerisinde ruhsal bozuklukları bulunan kişilerin şeytana tutulmuş olduğu düşüncesiyle yargılanıp öldürülmesi sona ermiştir. Ruhsal bozukluklar konusunda en büyük adım 18. yüzyıla gelindiğinde Fransız ruh hekimi Pinel tarafindan atılır. Ruh hastalarının zincire bağlanması uygulamasına son veren Pinel'in başlattı̆g 1 bu insanî uygulama, bütün Avrupa'ya ve ABD'ye yayılarak hastaların hastanelerde ya da bakımevlerinde tedavi olmaya başlamasını sağlar.

19. yüzyıla gelindiğinde Fransa'da Esquirol, Morel, Magnan ve yüzyılın sonuna doğru Liebault, Bernheim, Charcot, Pière Janet; Almanya, Avusturya ve İsviçre'de Griesinger, Meynert, Hecker, Kahlbaum, Kraepelin, Breuer, Ferud, Bleuler, Jung ve Adler modern psikiyatrinin kurucuları olurlar. Söz konusu öncü ruh hekimleri, yeni hastalıklar tanımlayarak bunları kendi arasında sinıflandırırlar. $\mathrm{Bu}$ hekimlerin hemen hemen hepsinin ortak görüşü ruhsal bozuklukların beyindeki dejenerasyondan ileri geldiğidir.

Ruhsal bozukluklar konusunda çığır açan kişi ise Freud olmuştur. 19. yüzyılın sonlarında geliştirdiği "davranışları, insanın biyolojik kökenli güdüleri ile toplumun kendisine yönelik beklentileri arasındaki çatışmanın yarattı̆̆ dinamik güçlerle açıklayan” (Geçtan a, 1993, s. 17) psikanaliz kuram ile ruhsal bozukluklara dair anlayışı ve tedavi yöntemlerini derinden etkiler. Freud ile çağdaş olan Pavlov da koşullandırma ile öğretme çabalarına, koşullu terapi kavramı ile ruhsal bozukluklara ve bunların tedavisine farklı bir boyut kazandırır.

19. yüzyıl sonlarında ve 20. yüzyıl başlarında ruh hekimliğine büyük faydalar sağlayan Kraepelin, Adolf Meyer, Freud, Adler, Jung ve Pavlov'dan sonraki dönemlerde, özellikle II. Dünya Savaşı'ndan itibaren ruhsal bozukluklar ayrıntılı olarak tahlil edilmiş ve bunların tedavisinde büyük ilerlemeler sağlanmıştır.

\section{Paranoid Bozuklukların Tanımı, İçeriği ve Çeşitleri}

Fiziksel bir hastalıkla somut bir halde karşılaşabilirken, soyut bir nitelik taşıyan ruhsal bozuklukları belirlemek güçtür. Bu yüzden söz konusu bozukluklar beraberinde bazı sınırlamaları getirmektedir. $\mathrm{Bu}$ noktada normallik kavramı ortaya çıkar. Pek çok insan, normal ve normaldışı davranışların net bir şekilde ayrıldığını ve bir tarafta normal kişiler, diğer tarafta normal olmayan kişiler olduğunu düşünür.

Ancak, normal ve normaldışı davranışlar birbirinden ayrılırken bilimsel açıdan başvurulabilecek bir ölçü bulunmamaktadır. Bu konuda farklı görüşler açığa çıkar. Bunlardan ilki, "toplumsal normlara uyma oranının normali, bu kurallardan sapma oranının ise normaldışını belirlediği”" (Geçtan b, 1997, s. 12) görüştür. Bu görüşü savunanlar, toplumun kabul ettiği davranışların normaldışı sayılmayacağını düşünürler.

İkinci görüş, belli ölçülerde toplum kurallarına uymanın birlikte yaşamak için lazım olduğu, bunun zıttı tavırların kişinin hem kendisi hem de toplum için zararlı olacağıdır. Burada normallik için geçerli olan ölçüt, kişinin kendisini iyi hissetmesidir.

İnsanoğlu hayatı boyunca çevresine uyum gösterme gayreti içerisindedir. Uyum "dinamik bir süreçtir ve bireyin çevresinde yer alan değişikliklere karşı gelişstirdiği tepkilerle” (Geçtan b, 1997, s. 14) gerçekleşir. Uyum seviyesi ise kişinin kişilik özellikleri ve çevresinde karşılaştığ 1 durumlar tarafından belirlenir. $\mathrm{Bu}$ nedenle bir insanın uyum seviyesinin değerlendirilmesi son derece zordur. Çünkü insanın başarılı ya da mağlup olması, sadece biyolojik varlığını devam ettirmesi çerçevesinde değerlendirilemez; onun dünyadaki kendine özgü yeriyle değerlendirilir. 
Kișinin çatıșmalarla ve bunalımlarla dolu olduğu bir ortamda ruh sağlığını koruması için savunma mekanizmalarına başvurması son derece olağan bir süreç olup aynı zamanda zararsızdır. Ama kişi devamlı surette savunma mekanizmalarına başvuruyor, kendini yine kendisiyle ve toplumla çatışma halinde buluyorsa bu, beraberinde ruhsal bozuklukları da getirir. Bunların bazıları hafif şiddette olurken, bazısı kişinin kaldıramayacağı ağırlıktadır. Sıkça karşılaşılan ruhsal bozukluklardan birisi de paranoid bozukluklardır.

Paranoya kavramı ilk kez Eski Yunan'da kullanılmış ve Hipokrat zamanında da bilinen bir kelime olarak "delilik" anlamını taşımaktadır. Orta Çağ ve daha sonraki dönemlerde literatürden kalkan ve çoğunlukla karşılaşılmayan bu kavram, 18. ve 19. yüzyılda yeniden ortaya çıkmış ve farklı ruhsal bozuklukları tanımlamak için kullanılmıştır. 1863 yılında Kahlbaum, bu kavramı kullanmış ve bunu "süreğen, mantıkl, düzenli sanrllarla belirli bir ruh hastalığı" (Öztürk ve Uluşahin, 2011, s. 324) şeklinde tanımlanmıştır. Söz konusu kavramın bugünkü literatürde geçerli olan tanımı ise Kraepelin tarafından yapılmıştır. Ona göre paranoya "bir dizge içinde birbiriyle bağlantılı iyi düzenlenmiş acayip nitelik taşımayan sanrılarla giden, süreğen olan ama yıkıma yol açmayan" (Öztürk ve Uluşahin, 2011, s. 324) bir bozukluktur.

Miller ise 1941 yılında yayımlanan çalışması ile paranoid bozuklukları kalıtsal bir zemin üzerine oturtmaya çalışmıştır. Ancak hastanede tedavi görmüş ve tamamı paranoid bozukluk gösteren dört yüz hasta üzerinde yapmış olduğu kapsamlı araştırma, konuya açıklık getirmek için yeterli olmamıştır. Söz konusu yetersizliğin ortaya çıkmasında paranoid bozuklukların kalıtsal ya da yapısal bir zeminde husule geldiğini kanıtlayacak somut verilere ulaşılamaması temel etkendir.

Paranoid bozukluklar, "gerçek yaşamla ilişkili olabilecek sistemli sanrıların olduğu, görece az rastlanan fakat önemli etkileri olan bir psikotik bozukluktur" (Karanfil ve Orhan, 2010, s. 2) ve ileri yetişkinlik dönemlerinde daha sık karşılaşılan bir hastalıktır. Yaş ilerledikçe meydana gelen hayal kırıklıklarının artması, olanakların azalmaya başlayıp kişiyi sınırlandırması ve paranoid eğilimlerini dengede tutmayı başaran kişilerin yitimler ile karşılaştığında zorluklar yaşaması söz konusu bozukluğun genelde yetişkinlik dönemlerinde baş göstermesinin en önemli nedenidir.

İnanma ya da inanmama, güven duyma ya da kuşkulanma, olumlu ya da olumsuz beklentiler bir insanın olağan duygu hallerinin ve düşüncelerinin içinde yer almaktadır. Pek çok insanın hayatında başka insanlar tarafından önünün kesildiğine, karşısına engeller çıkarıldığına inandığı dönemleri vardır. Bu gibi dönemlerde kişiler çevresindekilere karşı kızgın, kırgın ve güvensiz olurlar. Ancak paranoid bozukluk yaşayan kişi "sürekli aldatılacağına dair bir beklentisinin olması gibi belirli fikir, meşguliyet ya da yersiz endişeler" (Shapiro, 2017, s. 44) taşıyarak bunları abartılı ve sürekli bir şekilde yaşar.

Paranoid tarzda olan kişiler genel olarak "sinsi, ketlenmiş, endişeli ve şüpheci insanlar ile katı bir biçimde kaba, daha agresif bir şüpheciliğe sahip, megaloman olanlar” (Shapiro, 2017, s. 43) diye iki gruba ayrılabilir. Her ikisinde de dramatik bir şekilde görülen hezeyanlı durumlar ağır derecede kişilik bozukluklarına uzanabilir. Hezeyanlarının içinde az da olsa gerçeklere dayanan bir taraf bulunsa da bu gerçekler paranoid kişiler tarafından abartılır ve gerçekten saptırılır.

Paranoid bozukluk yaşayan kişilerin bozukluk öncesi kişilik özelliklerini saptamak son derece güçtür. Gizli paranoid eğilim gösteren kişiler, bozukluğun baş göstermesinden önceki hayatlarında uyum mekanizmaları ve ego savunmaları ile bu durumu geçiştirirler. Her şeye karşın, bu bozukluğu yaşayan kişiler devamlı gergin, güvensiz, korkak olup yükselen kaygı seviyelerine saldırganlık ve öfke aracılığıyla boşalım aramaktadırlar. Bu kişiler kuşkucu, alıngan, kuruntucu bir mizaha sahiptirler. Çevresindekilerin "tutum ve davranışlarından kendilerine bir kötülük geleceği kuşkusuyla aşırı dikkatli, tetikte ve savunucu” (Çoban, 2009, s. 80) davranışlar içine girerler. Sürekli ihanete 
uğrayacağ 1 düşüncesiyle çok az sayıda kişi ile ilişki kurarlar. Bu kişiler hayatlarında her zaman yalnızlığa ve gizliliğe meyil gösterirler.

Paranoid kişilerin genelinde rastlanan bir diğer görüntü, bilinçaltındaki zayıflı̆̆ı gizlemek amaciyla büründüğü kendine yeterli gördüğ̈ tavırlarıdır. Başkalarının kendisi hakkında söyledikleri ile düşündüklerini normal bir insandan daha fazla önemser ve kolay ikna olmaz. Kabul görme ihtiyac1 zorluk derecesi arttığında savunmaya geçer ve şüphelerini doğrulayacak deliller aramaya başlarlar. $\mathrm{Bu}$ durumun yükselen bir ivmede seyretmesi genel kayg1 seviyesinin yükselmesine ve "temel güvensizliğin klşkırtılmasına" (Geçtan b, 1997, s. 143) sebebiyet verir.

Paranoid bozukluğu tetikleyen ana faktör, bir uyarılma neticesinde düşmanca ve cinsel dürtülerin denetimden uzaklaşmasıdır. Denetimden çıkan dürtüler "yansıtıcı, kuşkucu ve düşmanca duygularla grandiozite ve otonomi kaybu gibi korku ve sanrıların ön plana çıktı̆̆ zorlanmayı" (Aşt1, Acar, Bağc1 ve Bağc1, 2005, s. 27) beraberinde getirir. Bu, çoğunlukla, kişinin doyum kaynağını yitirmesi veya onu yitirme tehlikesi yaşamasında gerçekleşir. Yani paranoid patlama, kişinin anlamlandıramadığı devinimi olmayan arzularına ve güçsüz kalma korkularına karşı ortaya koyduğu abartılı bir dengeleme gayreti şeklinde düşünülebilir.

Paranoide meyilli kişiler, mağlubiyete uğradıklarında ya da başka kişilerin kendisiyle alay ettiği, küçük gördüğü hissine kapıldığında içine düştüğü zor duruma tahammül edemez. Çünkü ruh âleminde açığa çıkan yetersizlik düşüncesine karşı "geliştirdiği abartılı umutlar ve düşlerini sürdürebilmesi onun narsisistik desteğini yitirmemesine bağlıdır ve o da buna cesaret edemez” (Geçtan b, 1997, 144). Böyle bir olay yaşayan normal bir kişinin gururu kırılıp umudu kaybolurken, paranoid bir kişide ego bütünlügü büyük bir tehditle karşı karşıyadır.

Paranoid bozukluğun önde gelen sanrısal içeriklerine göre "erotomanik, grandiöz, persekütuar, somatik ve klskançlık" (Hocaoğlu, 2001, s. 100) olmak üzere çeşitli alt tipleri bulunmaktadır. Bunlardan ilki olan erotomanik tipte hasta "bir başka kişinin (obje) kendisini tutkuyla sevdiğine iliş̧kin sanrı geliştirdiği bir sendrom” (Topçuoğlu ve Göktepe, 1997, s. 61) yakalanmış olup söz konusu alt tip 1921 yılında De Clérambault tarafından tanımlanmıştır. Nadiren de olsa pasif karakter özellikleri taşıyan erkeklerde de görülmekle birlikte, çoğunlukla hasta bir kadındır. Erotomanik tipteki kişi, aşkını ilân etmeyen, ama alakasını belli eden biri tarafından sevildiğine ve istenildiğine inanmaktadır. Âşı olduğu kişi yüksek sosyal statüye sahip, toplum içinde direkt fark edilen birisidir. Erotomanik kişi, konuyla ilgili bir şey bilmeyen bu insanı, mektuplarıyla, ani ziyaretleriyle ve ilişkilerinin herkes tarafından bilinmesi gerektiğine dair talepleriyle aşırı boyutlarda rahatsız edebilir. Hatta durumu bazen polise ya da mahkemeye kadar taşıyabilir.

Bir diğer alt tip olan grandiöz tipte ise kişi, kendisini mucizevi boyutta kabiliyetli ya da çekici bulmakla başlar, akabinde bilim adamı, kâşif ya da peygamber olarak kökten bir değişimi gerçekleştireceğine dair bir inanç geliştirmeye kadar gidebilir. Grandiöz kavramının içeriği "kültürrel çevreyle yakından ilgilidir ve dini içerik en yaygını" (Saygılı ve Çalışkan, 1991, s. 39) olup derin kültürel faktörler ön plandadır. Süreklilik gösteren grandiöz tipinde kişi düşüncelerini oldukça sistemli şekilde organize eder. Bu tarz kişi bazen toplumsal ya da bilimsel bir hareketin parçası olabilir. Hatta az rastlanan bir durum da olsa kendisine müritler edinerek bir tarikat kurabilir.

Persekütuar tipte, kişideki bozukluğun başlangıcını, normal bir insanda da görülen iniş çıkışlardan ayırt etmek zordur. Ancak bu dönemde kişi gittikçe gerçek ilişkilerden uzaklaşır ve kendisindeki bilgilere yönelir. Çevresiyle iletişim kurmak için çabaladığında ise bunu hezeyanlarına göre icra etmeye çalışır. "Hezeyan içeriği basit ya da ince ayrıntılı olabilir" (Lapçın, 2007, s. 8). İlk başlarda ne olduğunu bilemez. İnsanlardan kendini soyutlayarak olayları ele alır ve bunlardan gizli anlamlar çıkarmanın peşine düşer. Diğer insanların gündelik konuşmalarını, davranışlarını, bakışlarını, 
gülümsemelerini gizlice seyreder ve adeta bir dedektif gibi bunların içeriğini çözmeye çabalar. Düşmanlık tipi ya da kovuşturulan tip olarak da adlandırılan persekütuar tip, paranoid bozukluğun en yaygın şeklidir.

Somatik tipte kişi herhangi bir fiziksel kusuru olduğuna ya da ciddi bir hastalığa yakalandığına dair yanlış düşüncelere saplanır. Devamlı surette kaygı duyar ve tetikte bekler. "Şiddetli bir enfeksiyona yakalandĭ̆gl, parazit infestasyonlart ile vücudunun sarlldı̆̆ hezeyanlarl” (Savrun, 2008, s. 115) ön plandadır. Vücudundan kaynaklanan kötü kokunun herkes tarafindan duyulduğuna, organlarının fonksiyonlarını yerine getirmediğine, derisinin içinde böceklerin hareket ettiğine, bedeninde olmadığı halde şeklen bozukluklar olduğuna dair hezeyanlarını görmek mümkündür.

Kıskanç tipte kişi, sevdiği kişiyi kaybettiğinde ya da kaybetme tehlikesi ile karşı karşıya kaldığında sevdiğine ya da rakibe karşı düşmanca hisler beslemeye başlar ve kendisine olan saygısı azalarak "zamanla işe yaramadiğı duygusuna kapılarak benlik saygısını kaybetmeye" (Tezcan ve Ülkeroğlu, 1995, s. 16) başlar. Bunlar kıskançlık duygusunun vücuda gelmesini sağlayan temel faktörlerdir. Kıskançlık duygusu, persekütuar tipteki kişinin hezeyanlarına yakın olan özellikler kazandığında dış dünyadaki gerçekleri çarpıtarak yeni bir ilişkiye adım attığında hezeyan niteliğine bürünür. Böylece kıskanç tip kendini doğrulayacak ipuçları bulmanın peşine düşer ve başkalarının ya da sevdiği kişinin davranışlarını sürekli yanlış anlar.

\section{Cemil Süleyman'ın Siyah Gözler Romanından Hareketle Bir Kadının Paranoid Bozuklukları}

Cemil Süleyman'ın Siyah Gözler romanının başkahramanı ismi belli olmayan bir kadın olup diğer kahramanlar kadının âşık olduğu genç adam, kadının hizmetçisi Gülter ve aşçı kadındır. Ancak romanın neredeyse tamamı evin sahibi olan kadın üzerine kurgulanmıştır. Dul biri olan bu kadın, Beykoz çayırının yanında bulunan evinde hizmetçisi ve aşçısıyla birlikte oturmaktadır. Daha önce başından bir evlilik geçmiş olan ancak çok sevip uğruna ailesini terk ettiği kocasının ihanetiyle sarsılan kadın için yaşadığı bu acı olay onun belleğinde olumsuz izler bırakır. Otuz yaşında olan kadın, kendisinden on yaş genç bir delikanlıyla onun ısrarları sonucu bir ilişkiye başlar. Ancak bu ilişki, bugüne kadar üstünü örtmeyi başardığı ve önceki hayatından miras kalan olumsuzlukların da etkisiyle kadındaki paranoid bozuklukları ortaya çıkarır. Sevdiği delikanlıya gün geçtikçe bağlanan, ancak bu bağlanmada kuşkulardan, evhamlardan yakasını kurtaramayan ve onun kendisini aldattığ hissine kapılan kadının bu hali, romanın sonunda genç adamı boğarak öldürmesine sebep olacaktır. Bu açıdan romanda kadın için iki aşama olduğu düşünülebilir. İlk aşama gencin aşkına karş11ık verip vermeme konusunda bocaladığı dönem olup bu dönemde onun paranoid bozuklukları harekete geçmeye başlar. İkinci dönem ise delikanlının teklifini kabul edip onunla ilişki yaşamaya başladıktan sonra kendini gösterir ki bu dönemde kadında paranoid bozukluklar dramatik şekilde kendini belli eder.

Paranoid bozukluklara yetişkinlik dönemlerinde daha sık rastlanmakta olup söz konusu durum kadınlarda kendini daha fazla göstermektedir. Romandaki paranoid tarzın sahibi de bir kadındır. Otuz yaşında olan bu kadın hayatın belli aşamalarından geçtiği için yetişkinlik döneminde sayılmaktadır. Büyük umutlarla yapmış olduğu evlilikte ihanete uğrayan ve hayalleri yıkılan kadın, son on yılını acılar içinde geçirmiştir. Kendisinden oldukça genç olan bir erkeğin onu sevip ona ilgi göstermesi ve kendisinden bir karşl1ık görmek istemesi onun "samimiyetlerin en yücelerinden birisi olan aşkın kıyısında yaşamasını" (Arslan, 2013, s. 33) sağlar, ama aynı zamanda kaygılarının açığa çıkmasına neden olarak paranoid bozukluklarını tetikler. Sevme, sevilme gibi olumlu hisleri korkuları altında kalır ve ne yaparsa yapsın ilk evliliğinin olumsuz etkilerini zihninden atamaz.

İşte evlilik hayatı... Hayatın bu ilk ve büyük aşkı... Ona umduklarının hangisini vermişti? Ve ondan, sonsuz mutluluklar beklediği için, ailesini bile 
terk ederek, geleceğini aşkına feda eden ve ancak bir an süren bir rüyadan sonra, birden bir ihanet darbesiyle, bütün emelleri kırılarak, on yıllık bir geçmişin elem verici yalnızlıkları içinde kahrolmuş ve perişan, sürüklene sürüklene otuz yaşını bitiren dul kadın, kendisi değil miydi? (Cemil Süleyman, 2004, s. 16-17)

Kadın, uğradığı hayal kırıklıkları ve imkânların sınırlanması ile uzun süredir barındırdığı paranoid eğilimlerini delikanlının kendisine olan ilgisini belli etmesine kadar dengede tutmayı sağlamıştır. Ancak kendisinden on yaş genç bir adamın aşkı, kadındaki kaygıların uyanmasına ve aşkı yeniden bulmuşken yine kaybedeceği korkusunun açığa çıkmasına neden olur. Kadın, daha kabul etmediği genç adamın aşkını kabul edip evlendiklerini hatta bu evliliğin de sonunun acı bir şekilde neticeleneceği düşüncesi ile "kendisini aşırı kasvetin içine daldırır" (Adler, 2008, s. 54) ve bunların sonucunda baş başa kalacağı zorluklarla nasıl mücadele edeceğini düşünür. Dul bir kadın olması, geleneksel Türk toplum hayatının koymuş olduğu kurallar, üstüne genç adamın ilgisiyle karşılaşması onun bastırmış olduğu duygularını açığa çıkarır.

İnsan hayatındaki durumların ve düşüncelerin içinde güvenme ya da kuşkulanma, olumlu ya da olumsuz beklentiler her daim var olan şeylerdir. Ancak kadın için bunlar delikanlının kendisine olan ilgisini öğrendiği andan itibaren değişime uğrar. Genç adamın kendisinin önüne bir mektup atarak ondan ertesi gün için bir görüşme talep etmesi kadının o geceyi ateşler ve titremeler içinde geçirmesine sebep olur. Acı dolu ve güvensiz olan kadın, paranoid bozukluklarının da gün yüzüne çıkmaya başlamasıyla bu durumları abartılı bir şekilde yaşar. Öyle ki gece odasında otururken birden delikanlıyı karşısında görür ve ona sarılarak adeta aşka gelir.

(...) onu kolları arasında sıkıyor; hırpalanmaktaki zevki sanki damla damla içmek isteyerek ruhunun bu sinirlerini yakan ihtiyacıyla her dakika kendisini ona bir parça daha teslim ederek yavaş yavaş kendisinden geçiyor ve birbirlerinin olan bu iki vücut arasında, hiçbir ayrılık kalmıyordu. (Cemil Süleyman, 2004, s. 19-20)

Birdenbire gördüğü hayalin etkisinden kurtulup gerçek hayata dönen kadının gördügü şeyler, aslında olmasını istediklerini içermektedir. Ancak o, bunları abartır. Genç adama olan kuşku ve güvensizlik, paranoid korkulara dair bir eğilim gösterir. Savunma mekanizmasını devreye sokar ve ertesi günkü buluşmaya gitmez. Akşamüstü dayanamayıp yine kaygılar içinde çayıra gezmeye gider ama delikanlıya rastlamaz. Bir süre sonra onu görse de genç adam hiçbir şey söylemeden kadının yanından geçip gider. Eve zar zor gelebilen kadın, yemek bile yemeden kendisini odasına atar ve yine derin düşüncelere dalar. Kadında kendini gösteren kendisine yetecek tavırlar onun alttaki zayıflığını gizlemek amacıyla taktığı maskedir. Aslında o, delikanlının kendisi hakkında hissedip söylediklerine çok önem vermektedir. Ancak buluşmaya gitmediği için onu görünce yanından geçip giden delikanlının kendisine tavır yaptığını düşünür. Bu durum onda bir mağlubiyet halinin oluşmasına sebep olur. Çünkü artık genç adamı sevdiğine emindir ve bundan ötürü korkuları artmaktadır: “(...) Böyle devam ederse, bugün, o kadar korkulan bu tehlike karşısında direnme gücünü yitiriverecek ve artık düzeltilemeyecek bir hata, ondan en kutsal bir şeyi uzaklaştırmış olacaktı. Bunu düşündükçe kaygıları artıyor" (Cemil Süleyman, 2004, s. 25).

Bir süre daha genç adamın ilgisine karşı koymayı başaran kadın, bir gün ondan gelen bir mektupla adeta yıkılır. Mektupta halasının Yeşilköy'deki evine gideceğini ve ondan uzaklaşacağını bildiren delikanlının sözleri kadının yüreğini parçalar. Gelgitler içinde, gözyaşları dökerek geçirdiği bir haftadan sonra pencereden bakarken geçen birini genç adama benzetir ve pardösüsünden onu tanır. $\mathrm{O}$ gün çayırda karşı karşıya gelirler. Delikanlı onun önüne yine bir mektup atar ve ertesi gün yine çayırda bir araya gelerek arabaya binerler. Romandaki kadının paranoid bozukluklarının başladığı ve gittikçe 
yükseldiği ikinci evre de işte bu andan itibaren başlar. Çünkü onun için doyum kaynağı olan genç adamı kaybetmesi ya da kaybetme tehdidi yaşaması gerçek anlamda kendisini gösterir.

(...) yüreğinde elem verici manevi bir yenilgi hissediyor; bir gün, artık heves alınmış, oynamaktan bıkılmış, kırık bir oyuncak gibi köşeye atılmaktan korkuyordu. Sonra onu kendisinden daha genç, daha güzel bir kadınla, yine böyle bir arabada gezmeye giderken görüyor; şimdi kendisine bol bol edilen iltifatların, o zaman bir başkasına yapılacağını düşünerek derin bir kıskançlık hissediyordu. (Cemil Süleyman, 2004, s. 61)

Yapmış olduğu evlilik neticesinde aldatılan ve terkedilen kadın, on yıl boyunca hayattan kendisini soyutlamış, evdeki hizmetçisi, aşçısı, birkaç komşusu ile uzaktan bir iki akrabası dışında hiç kimseyle konuşmamış ve iletişime geçmemiştir. Dış dünya ile delikanlı aracılığıyla yeniden temas kurabilmek için harekete geçtiğinde bunu hezeyanları ile icra etmeye çalışır. Ciddi anlamdaki ilk buluşmalarında delikanlının kendisini terk edeceğini, başka bir kadınla aldatacağını görmesi bunun somutlanmış hali olup aynı zamanda persekütuar tipin de bir belirtisidir. Kadın, aynı zamanda görüşmeleri esnasında kendisine evlenme niyetini açık eden gence karşı da son derece şüphecidir. Zira "huzuru aramak için çıktı̆̆ hayat yolunda kaosa sürüklenen dünyanın bunaltıcı ikliminden” (Arslan, 2017, s. 34) kendini kurtaramayan kadın için evlilik kavramı belirsiz bir durumdur. Ancak onun bununla ilgili olarak bir başka kişiye danışacak güveni yoktur. Zaten iletişimde olduğu kişi sayısı da son derece sınırlıdır. Yansıttığı korkularından arınamadığı için şüphelerini herhangi bir sınamaya tabii tutmadan sıralar: "Yoksa onu aldatmış mıydı? Bu ihtimalle birden yüreği çarptı. "Kim bilir?" dedi. Belki de öyle... Insanlardan her şey beklenirdi” (Cemil Süleyman, 2004, s. 65).

Kadındaki şüpheci düşünce, dramatik ve etkileyici bir şekilde katıdır. Zihninde belirli olan şey, delikanlının kendisine ihanet edeceği düşüncesidir. Bu nedenle yaşadığı ilişkiye "sabit ve kafasını kurcalayan bir beklentiyle yaklaşır" (Shapiro, 2017, s. 45) ve tekrar tekrar aynı düşünceyi zihninde dile getirir. Genç adam ona olan aşkını ilân edip onunla evlenmek istediğini belirtse de kadın bunu doğrulayacak verilerle ilgilenmez. Delikanlı, kadındaki paranoid bozukluğun farkında olmadığı için onu aldatmadığına dair bir ikna çabasının içinde değildir. O, kendisine kesin olarak ihanet edeceğini düşünen kadının kökendeki şüpheci hislerinin nesnesi haline gelir.

Kısa süre içinde delikanlıyla arasındaki ilişkiyi ilerleten kadın, bir akşam buluştuklarında aşkın şiddetli arzularına boyun eğerek ona bedenen de teslim olur. Eve sabaha karşı gelen kadın, odasına geçip yine düşüncelere dalar. Yaşadığı tensel hazzın zevki kısa süre içinde yerini derin şüphelere bırakır. Çayırda gezerken ara sıra gördüğü bir kızın, genç adamla arasında münasebet olduğuna dair bir inanca kendini kaptırır. Kadının bu durumu paranoid rahatsızlığından kaynaklanırken, şüpheci tavrı herhangi bir bilgi ya da bilgiler topluluğunu göz ardı etmesinin bir sonucudur. Ancak kadın söz konusu bilgiye olağanüstü bir önyargıyla yaklaşır ve varsayımını haklı çıkaracak kısmı benimsemeyi tercih eder.

(...) sonra gözünün önünden bir hayal geçiyor; her zaman yanından geçerken ona gülümseyen genç kızı düşünüyordu. Birden, o zamana kadar duyulmamış bir kaygıyla: "Acaba?" dedi. Acaba aralarında bir şey var mıydı? Bunu şimdiye kadar bu derece derin düşünmemişti. Oysa o, kendisinden daha gençti. Ve belki de, bir gün kendisine rakip çıkabilirdi. (Cemil Süleyman, 2004, s. 77)

Kadının paranoid bozukluğunun kıskanç tip olarak görüldüğü yukarıdaki satırlarda, sevdiği adamı kaybetme tehlikesi ile çayırda tesadüfen karşılaştığı bir genç kızı rakip olarak beller. Zihninde rakip olarak belirlediği bu kız zamanla onun için bir düşman konumuna gelir. Çünkü bu kız, kadından yaş 
olarak gençtir ve onun kendisine olan saygısını azaltarak kıskançlık duygularını kabartır. Kadın, şüphelerini haklı çıkarmak için araştırmaya karar verir. Bu açıdan o, sadece hayal eden değil aynı zamanda araştırandır. Araştırmakla da yetinmeyip, kapasitesinin üstüne çıkabilecek bir keskinlikle işe girişir ve ertesi gün sabah erkenden çayıra iner. Ancak çayıra indiğinde herkesin ona baktığ 1 düşüncesine kapılır. Kendisini hedef aldıklarını ve onu yaftaladıklarını düşündüğg̈ bu topluluğu sanki gerçekte varmış gibi zihninde oluşturur.

Tesadüfen gözüne ilişen bakışlarda, kendisini inceleyen gizli bir alev fark ediyordu. Birer birer gelen aileler, ötede beride halkalar yapıyorlar; zaman ilerledikçe kalabalık artıyordu. Bugün herkeste bir başkalık vardı. Bakışlar daha merakl1, yüzler daha manidard1. (...) Şimdi kendi kendisine, buraya niçin geldiğini düşünüyor; çevresini görmemek için gözlerini çeviriyordu. Demek artık çayıra da inmemeliydi. (Cemil Süleyman, 2004, s. 78)

Kadın için bu aşamaya gelinceye kadar belirli bir odaktan gelen herhangi bir tehlike söz konusu değildir. Ancak önce çayırda gördüğü genç kızı, daha sonra onun izini sürmek için indiği çayırdaki insan topluluğunun kendisine karşı kötülük yapmaya çalıştığına inanır. Bu topluluk, kendini merkez olarak algılayan paranoid kadın tarafından kendisine zarar vermeye çalışan ve bu nedenle bir araya gelmiş insanlar olarak nitelendirir. Halbuki söz konusu bu insanlar bir “düzmece topluluk”'tan (Geçtan b, 1997, s. 145) ibarettir.

Kadın ve genç adamın buluşmaları bir süre sonra kadının evinde gerçekleşmeye başlar. Geceleri hizmetçisi ve aşçısı uyuduktan sonra delikanlıyı gizlice evine alan kadın, odasında sabaha kadar onunla beraber olur. Ancak bu buluşmalar, ondaki şüphelerin, ihanet korkularının ve hezeyanların gittikçe artmasını sağlar. Gencin gelmediği bir gece odasında otururken rakip gördüğü kızın kendisiyle dalga geçen suretini görür ve bu rekabet onu korkutarak gözündeki düşman algısını yoğunlaştırır.

Ona alaycı bakışlarla gülümseyen bir genç kızın, gözünün önünde yükselen gepegenç heykelini görüyordu. O dururken kendisini mi sevecekti? Birden, bu kızı karşısında bir rakip hissiyle görmekten titredi. (...) Fakat nereye gitse, bu hayal onu izliyor; bütün düşüncelerinde onu rahatsız edip acı veren bu duygu, ruhunda gittikçe derinleşen bir kıskançlık yaratıyordu. (Cemil Süleyman, 2004, s. 90)

Kadının bilinç denetiminden uzaklaşan kıskançlık duygusu, artık hezeyan özelliğini alır. Kadını bu denli korkutup tedirgin eden kızın hayalinin karşısına geçip ona alaycı şekilde gülümsemesi, onun geliştirmiş olduğu gerçek olmayan senaryoların bir neticesidir. Kadın, sevdiği adamın kendisini bu kızla aldatacağı kuşkusuyla ona karş1 "bilinçdışı bir düşmanlık da yaşar; çünkü varlığı ona kendi yetersizliğini hatırlatır" (Geçtan c, 2016, s. 75) ve onun kendine olan saygısını yitirmesine sebep olur. Düşmanlık duygularının artması kıskançlığına da aynı oranda yansır.

Günler geçtikçe kadındaki paranoid bozukluklar iyiden iyiye kendini belli etmeye başlar. Evdeki hizmetçisi ve aşçısı ondan korkmaya başlarlar, ancak kadın, onlara her şeyin normal olduğunu göstermek için yoğun çaba harcar. Delikanlı da kadındaki garip davranışların farkına varır. Gerçekte kendisini mutsuz etmek için ciddi bir enerji harcayan kadın, kendisine eziyet etme konusunda da yüksek bir kabiliyet gösterir. Delikanlının yanına geldiği zamanlarda da onu kendisini aldatmakla suçlar ve kıskançlığından haykırma derecelerine varır. Bu anlarda artık kendini kaybetmeye başlayan kadının bu hali, genç adamda bıkkınlık ve soğuma hislerini körüklemekten başka bir işe yaramaz. Kıskançlı̆̆ın adeta müptelası haline gelen kadın "ona acı veren ve küçük düşüren bir çlkmaza kök salmış” (Blèvis, 2010, s. 57) gibidir. Yaşadığı kıskançlık nöbetlerini son derece şiddetli geçirmekte ve 
onun büyük bir acı duymasına sebebiyet vermektedir. Ancak o yine de kendisini merkez alır ve haklı bulur.

Seven, her zaman kıskanırd1. Ve bu, onun ruhunda öyle şiddetli isyanlarla her an taşmaya hazır bir duyguydu ki onda aşırı ve hastalıklı bir duyarlılık yaratan şiddetli bir beyin rahatsızlığı şeklinde ortaya çıkıyordu. Her şey onu etkiliyor ve üzüyor; arada bir, sebepsiz yere saatlerce ağliyordu. (Cemil Süleyman, 2004, s. 95)

Ona göre hayatı büyük bir mağlubiyetten ibaret olan kadının, bu düşüncesinin esas nedeni başından geçen evliliğinde uğradığı ihanettir. Yıllar sonra yeniden bir ilişkiye adım atan kadının o güne kadar üstünü örtmeyi başardığı paranoid bozukluklarının bu ilişki içinde açığa çıkışı, kadının adama olan kıskançlığını da salıvermesini sağlar. Acısını besleyip büyüten kadının, delikanlının evine gelmediği gecelerde, ona karşı olan kıskançlığı büyümektedir. Onun dış dünyaya özellikle rakip olarak zihnine yerleştirdiği diğer kızın tarafına çekildiği hissi kadını yiyip bitirir. Böylece tanımadığı ancak kendisinde olmadığını düşündüğü gençlik gücünü elinde bulundurduğundan emin olduğu kıza düşmanca hisler besleyerek kendini tüketmektedir.

Son günlerde rüyalarında bile delikanlı ile genç kızın seviştiğini gören kadının zihnini uğraştıran tek düşünce, her şeyi bildiği halde hala onu aldatmak istemeleridir. Oturduğu yerde onları kol kola giderken gören, onların seslerini işiten kadın, kendisine eziyet edildiği şeklinde bir hezeyan geliştirmiştir. Oysa on y1l önce ailesini çiğneyerek evlendiği adam, kadına ihanet edip evliliklerinin bitmesine sebep olduktan sonra onu büyük üzüntülere gark etmiştir. Dolayısıyla hoşgörü gösteremediği şey net olarak ortadadır. O, âşı olmuş, ihanete uğramıştır ve insanların söylediğini düşündükleri aslında onun kendi kendisine söyledikleridir. Kadının "yakındiğı şeyin içeriği deforme edilmemiştir” (Mellor, 2012, s. 45) ama bunu başkalarına söyletip onların hainliklerini protesto ederek reddetmektedir. Bir kez daha yenilmiş olma fikrine tahammül edemeyen kadın, geliştirmiş olduğu ihanet paranoyasının son aşamasına geçer. Gece evine gelen genç adamın, bir daha yanından giderse kendisine dönmeyeceğine emindir ve onu dizlerinde yatmaktayken boğarak öldürür.

Birden heyecanları öfkeyle taşkınlaşarak kendisini kaybetti. Ve ne yaptığını bilmeyen öfkeli bir kaplan saldırısıyla delikanlının üzerine kapandı. Artık hiçbir şey düşünmüyordu. Sağlam ve heyecanlı kolları arasında, bu narin ve zayıf vücut kıvranıyor; kasılıyor; arada bir direnmek isteyen umutsuz bir azimle bükülerek, kıvrılarak, güçsüz hamleler gösteriyor; ama her saniye bir az daha güçten düşerek kendisini kadının kollarına teslim ediyordu (Cemil Süleyman, 2004, s. 109-110)

Tüm hayatı "kendini açı̆̆a vurma arzusu ile kendini gizleme arzusu arasında bölünmüş" (Laing, 2015, s. 35) olan kadının menzili dışında kalan her şey ondaki şüpheleri ve tehditleri körükler. Yaşamış olduğu deneyimleri ve hezeyanları da sevdiği delikanlıya karşı devamlı surette ürettiği sadakatsizlik senaryolarının delili yapar. Daima delikanlının kendisinden bir şeyler sakladığından şüphelenir ve artık hiçbir şey onun hislerini bilme isteğini dindirmemeye başlar. En ufak bir şeyde kuşkularının tavan yapmasına izin veren kadın, varsayımsal sadakatsizlik kurguları yapmayı alışkanlık haline getirir. O gece, "seni aldatıyor, onu öldür" şeklindeki hezeyanları, aslında kadının kendi içindeki saldırgan dürtülerin bir yansımasıdır. Genç adamı dizinde yatarken boğması esnasında ve yazarın kendisini bir kaplana benzettiği satırlarda dışarıya yansıttığı, kendi içinde kendini gözetleyen güçtür. Dışarıdan algılanan ses ve yine ihanete uğrayarak terkedileceği düşüncesi onu büyük korkulara sokarak delikanlıyı öldürmesine kadar gider. 


\section{Sonuç}

Cemil Süleyman'ın Siyah Gözler'i, başkahramanı olan kadının paranoid bozukluklar gösterdiği ve söz konusu bozuklukların karma bir halde karşımıza çıktığı bir romandır. İlk evliliğinde ihanete uğrayarak hayal kırıklığına uğrayan kadın, on sene boyunca dış dünyadan kendisini soyutlamış; hizmetçisi, aşçısı, birkaç komşusu ve bir iki uzak akrabasının dışında hiç kimse ile iletişime geçmemiştir. Uzun bir aradan sonra genç bir erkek tarafından beğenilmek onun yeniden dış dünya ile irtibata geçmesini sağlamıştır. Ancak bu durum, onun o güne kadar bastırdığı paranoid bozuklukların harekete geçmesine zemin hazırlamıştır. Kadın, daha delikanlının teklifini kabul etmediği halde, belli bir dayanak olmaksızın delikanlının kendisini sömürdüğünden, aldattığından kuşkulanmaktadır. İlişkileri başladıktan sonra da genç adamın kendisine olan bağlılığı adına derin tereddütlerine devam eder. Delikanlı ile yaşadıklarının, ona söylediklerinin kendisine karşı komplo olarak kullanılacağı gibi düşüncelerle dolu gereksiz korkularla kendini kuşatır. Bu nedenle başka insanlarla da söz konusu durumları hiçbir şekilde konuşmaz ve paylaşmaz. Herhangi bir sözü ya da davranışı kendisi için bir tehdit ya da aşağılama şeklinde algılar. Kafasında yarattığı olmayan bir rakibe ve topluluğa karşı düşmanca yaklaşımlar gösterir. Olmadık yerde delikanlının kendisine ihanet ettiği konusunda kuşkular duymaktadır. Sonunda kesin olarak aldatılıp terkedileceği yargısına varır. Hezeyanlarının da tetiklemesiyle içindeki tüm öfkesiyle dizlerine yatmış olan genç adamı boğarak öldürür. Tüm bunlar, paranoid bozuklukların ölçütü olup romandaki kadının hal ve tavırlarına da dramatik bir şekilde yansır. $\mathrm{Bu}$ açıdan roman, bir kadında persekütuar ve kıskanç tip olarak harmanlanmış paranoid bozuklukları detaylı olarak ele alması ve yazarın bunu başarılı bir şekilde fiktif âleme aktarması bakımından yayımlandığı dönem için son derece önem teşkil eder. 


\section{Kaynakça}

Adler, A. (2008). Nevroz Sorunları. Ali Kılıçoğlu (Çev.). İstanbul: Say.

Arslan, F. (2013). Hayat Arası Öyküler ya da Umran Nazif Yiğiter. Erzurum: Salkımsöğüt.

Arslan, F. (2017). Atilla İlhan'ın Şiir Kadınlarında Annelik Biçimleri: Sığınma, Doğurgan, Sevgili... Ulakbilge Sosyal Bilimler Dergisi 5 (9), 29-41.

Aşt1, N., Acar, G., Bağcı, H., Bağcı İ. (2005). Sağlık Bakım Profesyoneli Olarak Yetişecek Öğrencilerin Ruhsal Durumları ve Yaklaşımlar. Muğla Üniversitesi Sosyal Bilimler Enstitüsü Dergisi $15,25-35$.

Berksoy, B. (2003). Fecr-i Âti Yazarlarından Cemil Süleyman Alyanakoğlu'nun Hayatı, Şahsiyeti, Eserleri ve Eserlerinin Feminist Eleştirel İncelemesi (Yayımlanmamış yüksek lisans tezi). Yeditepe Üniversitesi Sosyal Bilimler Enstitüsü, İstanbul.

Blèvis, M. (2010). Kıskançlık. Işıl Aydın (Çev.). İstanbul: Sel.

Cemil Süleyman (2004). Siyah Gözler. Kemal Bek (Haz.). İstanbul: Bordo Siyah Klasik.

Çoban, A. (2009). Şizofreni Bin Parça Akı1. İstanbul: Timaş.

Geçtan a, E. (1993). Varoluş ve Psikiyatri. İstanbul: Remzi.

Geçtan b, E. (1997). Psikodinamik Psikiyatri ve Normaldıșı Davranışlar. İstanbul: Remzi.

Geçtan c, E. (2016). İnsan Olmak. İstanbul: Metis.

Hocaoğlu, Ç. (2001). Paranoid Semptomlar ve Sendromlar. Psikiyatri Dünyası 5, 97-104.

Karanfil, R., Akçan, R., Orhan, Ö. (2010). Çocuğun Cinsel İstismarı ile İlgili Asılsız İddialar ve Paranoid Bozukluk: İki Olgu Sendromu. Türk Psikiyatri Dergisi 21, 1-5.

Laing, R. D. (2015). Bölünmüş Benlik. Ergün Akça (Çev.). İstanbul: Pinhan.

Lapçın, S. (2007). Paranoid ve Nonparanoid Şizofreni Hastalarının Bilişsel Fonksiyonlar ve Silik Nörolojik Belirtiler Açısından Paranoid Bozukluk ve Sağlıklı Kontrol Grubu ile Karşılaştırılması (Yayımlanmamış uzmanlık tezi). Sağlık Bakanlığı, İstanbul.

Mellor, S. M. (2012). Paranoya. Işı1k Ergüden (Çev.). Ankara: Dost.

Öztürk, O., Uluşahin, A. (2011). Ruh Sağlığı ve Bozuklukları I. Ankara: Nobel Tıp.

Savrun, M. (2008). Hezeyanlı Bozukluk. Müfit Uğur, İbrahim Balcığlu ve Neşe Kocabaşoğlu (Ed.). Türkiye'de Sık Karşılaşılan Psikiyatrik Hastalıklar (s. 111-116). İstanbul: İ. Ü. Cerrahpaşa Tıp Fakültesi Sürekli Tıp Eğitimi Etkinlikleri.

Saygıl1, S., Çalışkan, M. (1991). Toplumda Zaman Zaman Sansasyonlara Neden Olan Mistik Hezeyanlı Bir Paranoya Vakası. Düşünen Adam 4 (2), 37-39.

Shapiro, D. (2017). Nevrotik Tarzlar. Şehnaz Layıkel (Çev.). İstanbul: İstanbul Bilgi Üniversitesi.

Tezcan, A. E., Ülkeroğlu, F. (1995). Patolojik Bir Kıskançlık Vakası. Düşünen Adam 8 (3), 15-17.

Toğçuoğlu, V., Sarıbeyoğlu, S., Göktepe, E. (1997). Bir Olgu Dolayısıyla Erotomani Kavramının Gözden Geçirilmesi. Düşünen Adam 10 (3), 61-64. 